\title{
鋼構造ラーメン骨組の魚骨形地震応答解析モデル \\ MODELING OF THE MOMENT RESISTANT FRAME TO FISHBONE-SHAPED FRAME FOR THE RESPONSE ANALYSIS
}

\author{
小川厚治*, 加村久哉**, 井上一朗*** \\ Koji OGAWA, Hisaya KAMURA and Kazuo INOUE
}

\begin{abstract}
It is important to estimate the required cumulative plastic deformation of members against strong earthquake for seismic design. The conventional model which has been generally used for seismic response analysis is equivalent multi-mass shear vibration system. The collapse mode of steel structure can not be predicted in a strict sense with this system, because the strength and stiffness ratios of the column and the beam are not estimated by the model. On the other hand, multistory planar frame model is not undesirable for practical use, because too much effort, such as design of the frame and analysis to carry out parametric study, is needed. This paper proposes the formulation of modeling of the multistory planar moment resistant frame to fishbone-shaped frame, which can predict the collapse mode, and cumulative plastic deformation of member for the seismic response analysis. And the propriety of the modeling is presented by numerical examples.
\end{abstract}

Keywords : multistory planar frame, fishborn-shaped frame model, joint panel, collapse mode, seismic response, story drift angle, cumulative plastic deformation

多層平面骨組, 魚骨形骨組モデル, 接合部パネル, 崩壊型, 地震応答, 層間変形角, 累積塑性変形

1. 序

鋼構造建築物の耐震安全性を評価し確保するためには, 大地震時 に各部材に要求される塑性変形能力を定量的に把握する必要があり， これは部材レベルの弾塑性構成則を導入した数值計算によって可能 となる。このような解析方法は単純塑性ヒンジを用いた方法りに始 まり，一般化塑性ヒンジ法を用いた方法2,3)も提案されている。ささら に, 1 次元有限要素法4)用いれば, 部材断面の平均歪度レベルの 情報も得ることができる，ただし，これらの方法では，ある特定の 骨組に関する応答值は得られるが, 部材の変形応答に及ほすす多くの 構造パラメー夕に対する広範な数值計算に必ずしも適切な方法とは いえない, 一方で, 層間変位などの概括的な応答の算定を目的とし てせん断型多質点系モデルが用いられてきた ${ }^{5,6)}$.しかし, せん断型 モデルは厳密には各層の耐力・剛性が独立に決定される骨組に適用 できるものであり，層間変位応答の高さ方向分布に及ほす柱梁耐力 比の効果や部材レベルの変形を直接評価することはできない.

平面ラーメンを対象とすれば, 部材に要求される塑性変形能力は, 層せん断耐力・剛性の高さ方向分布, 崩壊型に影響を及ぼす柱梁耐 力比などの部材間耐力比, 柱梁剛比などに影響される. 本論では,こ れらの情報が反映可能なモデルとして魚骨形骨組を利用することを 提案する. 魚骨形骨組は, 均等無限スパン骨組を想定したモデルと して, また中柱周りの挙動を定性的に検討するモデルとして以前か
ら用いられてきた7)。ここで提案する魚骨形骨組は，現実的な多層 多スパン骨組の地震応答を近似するためのモデルである.本論では, ラーメン構造の崩壊型などの特性が再現でき, 部材レベルの応答も 評価可能な魚骨形骨組へのモデル化の方法を示す。

\section{2. 魚骨形骨組へのモデル化の考え方}

本論では図 1 に示す多層平面骨組の魚骨形骨組へのモデル化につ いて述べる.モデル化された魚骨形骨組の柱および梁を元の骨組の 柱, 梁と区別するために, それぞれ「魚骨柱」,「魚骨梁」と呼ぶ. 以 下, 単に柱・梁と呼ぶのは元の骨組の部材である. 魚骨梁は節点の 回転を拘束するバネであり，解析上は弾塑性回転バネとして扱う。

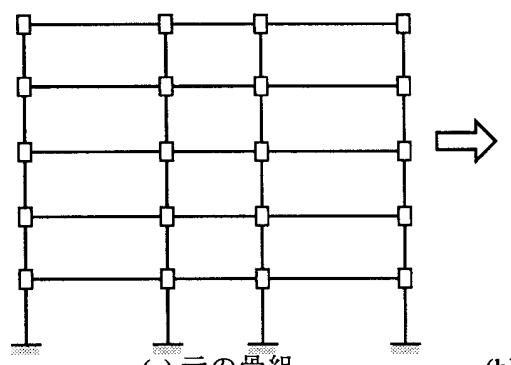

(a) 元の骨組

(b) 魚骨形骨組

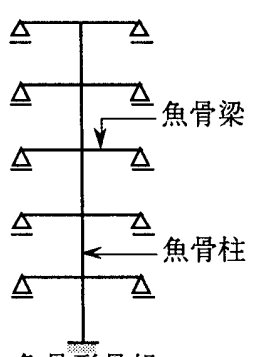

図 1 魚骨形へのモデル化

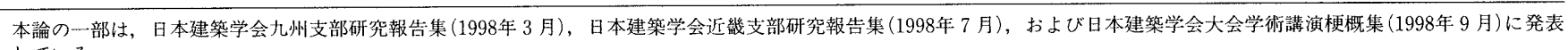
している。

* 熊本大学工学部環境システム工学科 教授・工博

Prof., Dept. of Architecture and Civil Engineering, Faculty of Engineering, Kumamoto Univ., Dr. Eng.

** NKK 基盤技術研究所 主任研究員・工修 Senior Research Engineer, Applied Technology Research Center, NKK Corporation, M. Eng.

*** 京都大学工学研究科生活空間学尃攻 教授・工博

Prof., Dept. of Architectural and Environmental Design, Faculty of Engineering, Kyoto Univ., Dr. Eng. 
魚骨形骨組へのモデル化の問題は, 魚骨柱と魚骨梁の剛性と耐力抢 よびそれらの復元力特性をいかに設定するかに帰着される。魚骨形 モデルでは，接合部パネルの剛性・耐力，ざらに骨組のせん断剛性 に及はす柱の軸方向変形の影響を考慮することも可能である。

ここで提案する魚骨形モデルは, 主に以下の仮定に基づいている。 [1] 同一床レベルにある節点の水平変位·節点回転角はすべて等しい.

[2] 各柱, 各梁の反曲点はその内法長さの中央にある.

[3] 各柱㧍よび各梁はすべて一様断面である.

魚骨形モデルは，各層に水平变位と節点回転角の $2 つ の$ 自由度を 考慮するので, 全自由度はせん断型モデルの 2 倍になる.しかし，魚 骨形モデルは，梁や接合部パネルの変形・耐力を暧昧に考慮するせ ん断型モデルに比べると, 各部の剛性・耐力評価は理論的に明快で あり，柱・梁・接合部パネルの部材レベルでの損傷を評価できると いう利点がある.

\section{1 魚骨柱・魚骨梁の弾性剛性}

前節の仮定[1]から，1つの層を構成するすべての柱の上側の節点 回転角, 下側の節点回転角, 部材角は等しいので, 魚骨柱の弾性剛 性マトリックスは, 元の骨組の層を構成するすべての柱の弾性剛性 マトリックスの和である. 図2左のようにその層の柱以外は剛体と した構造を考えれば，魚骨柱の剛性は単純に評価できる。

梁や接合部パネルの弾性変形は, 魚骨梁の弾性変形として考慮す る. 図3左に示すように, 柱の弾性変形を無視すると梁と接合部パ ネルが変形しても，上下の柱は剛体的に同じ角度だけ回転する。魚 骨梁は, このような魚骨柱の剛体回転を床レベルで拘束するバネで ある。したがって魚骨梁の弾性剛性は, 柱を剛体とした図 3 左の構 造物に作用するモーメント $M(=Q H)$ と変形角 $R$ の剈性である.
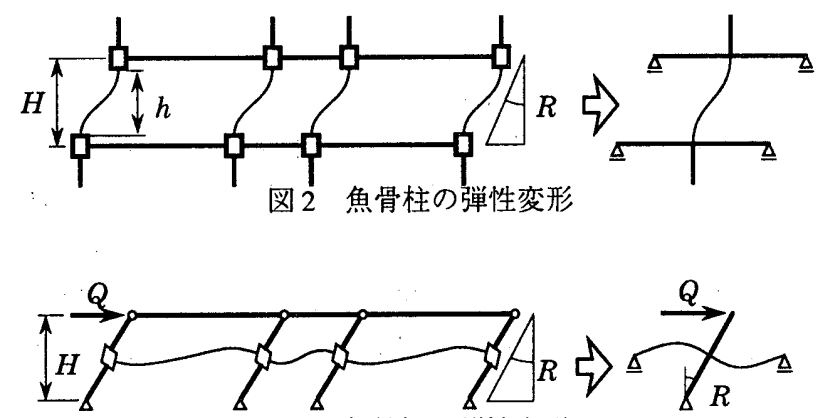

図3 魚骨梁の弾性変形

\section{2 魚骨形骨組の崩塄機構と各部の耐力}

図4左に示すような骨組の崩壊機構は, 魚骨形モデルでは図 4 右 のように表される.図4左の例は，2層にわたる崩壊機構であり，黒 丸が塑性ヒンジ位置，灰色の接合部パネルが降伏している，中間の 床レベルでは, 梁は1端だけしか塑性ヒンジを形成しておらず，柱 にも塑性ヒンジが形成されているが，この床レベルでの塑性変形は 魚骨梁の塑性変形として考慮する。

図 4 に示した $2 つ の$ 構造物の崩壊荷重を等しくする，すなわち， 一定変形下での塑性歪エネルギーを等しくするという条件から, 魚 骨形モデルの各部の耐力は評価できる.

すなわち，魚骨柱の柱頭の塑性モーメントは，対応する層の柱の 柱頭側の塑性モーメント和であり，魚骨柱の柱脚の塑性モーメント

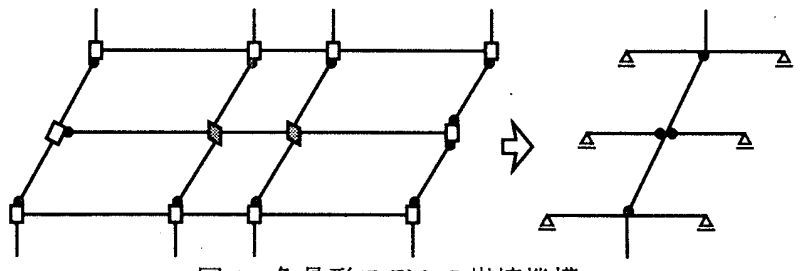

図 4 魚骨形モデルの崩壊機構

は，対応する層の柱の柱脚側の塑性モーメント和である.

中間の床レベルでの抵抗モーメントを, 図 4 左の骨組の例で個々 の節点について考えると, 左端節点のように梁が降伏する場合は梁 端モーメントであり，中柱節点のように接合部パネルが降伏する場 合はパネルモーメントであり, 右端節点のように柱が降伏する場合 は柱端モーメント和となる. 床レベルでの抵抗モーメントは以上の 値の和, すなわち, フロアモーメント8) として評価できる. 魚骨梁 の塑性モーメントは, 元の骨組のフロアモーメントである.

以上のように魚骨柱と魚骨梁の耐力を設定すると, 柱・梁・接合 部パネルの各部が降伏したときの節点位置での曲げモーメントが既 知の骨組については，任意の水平荷重分布に対する魚骨形モデルの 崩壊機構は元の骨組と同じになる.

\section{3. 魚骨形モデルの作成}

\section{1 弾性剛性}

\section{1 .1 魚骨柱の弾性剛性}

図2左のように上下の節点が回転せずに層間変位角 $R$ だけが生じ る状態では, 柱は逆対称曲げを受け, 上下端の曲げモーメントが等 しくなる.このような場合, $i$ 層の 1 本の柱の一端での曲げモーメン トと柱部材角の剛性 $K_{C i}$ は，せん断変形を考慮して次式で表せる.

$$
K_{C i}=\frac{1}{\left(h_{i} / 6 E I\right)+\left(2 / G A_{S} h_{i}\right)}
$$

ここで, $E$ はヤング係数, $I$ は断面 2 次モーメント, $G$ はせん断弾性係 数, $A_{S}$ はせん断断面積, $h_{i}$ は柱の実長 (接合部パネル間での内法長 さ)である.(1)式は, 接合部パネルの大きさを無視したときの剛性で ある. $H_{i}$ を $i$ 層の階高（節点間距離）とすると, 柱端での曲げモー メントは節点位置での曲げモーメントの $h_{i} / H_{i}$ 倍になり, 矰間変位 角は柱の部材角の $h_{i} / H_{i}$ 倍となる.したがって, 接合部パネルの大 きさを考慮した $i$ 層の柱の剛性 $K_{C i}^{*}$ は次式となる.

$$
K_{C i}^{*}=\frac{1}{\left(h_{i} / 6 E I\right)+\left(2 / G A_{S} h_{i}\right)} \frac{H_{i}^{2}}{h_{i}^{2}}
$$

$i$ 層の魚骨柱の弾性剛性 $\overline{K_{C} i}$ は $i$ 層を構成するすべての柱の剛性 和として次式で求められる。

$$
\overline{K_{C i}}=\Sigma K_{C i}^{*}
$$

魚骨柱は，上記の剛性 $\overline{K_{C i}}$ をもつ一様断面の曲げ材とする。

\subsection{2 魚骨梁の弾性剛性}

魚骨梁の弾性変形は梁と接合部パネルの弾性変形の和で表される. 接合部パネルの両側の梁端の曲げモーメントが等しいと仮定すると, 梁の一端の節点位置での曲げモーメントと節点回転角との弾性剛性 $K_{B i}$ は，接合部パネルの大きさを無視すれば次式となる.

$$
K_{B i}=\frac{1}{\frac{l}{6 E I}+\frac{2}{G A_{s} l}+\frac{m}{G V_{P}}}
$$




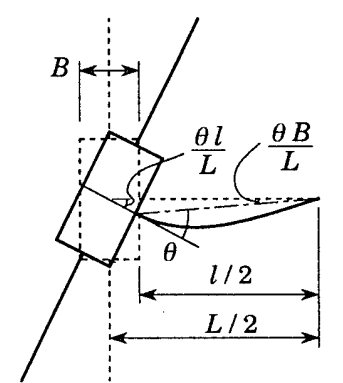

図 5 梁の弾性変形

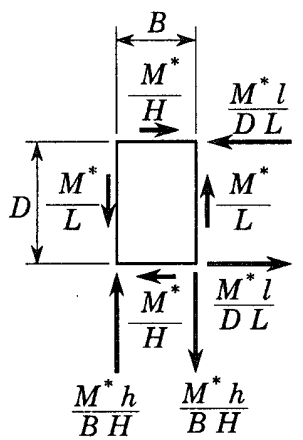

図 7 接合部パネルの応力

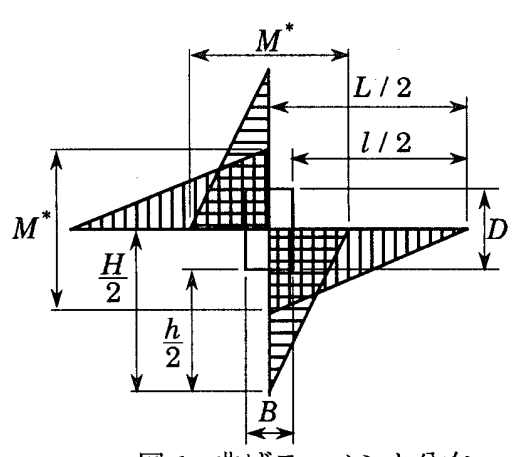

図 6 曲げモーメント分布

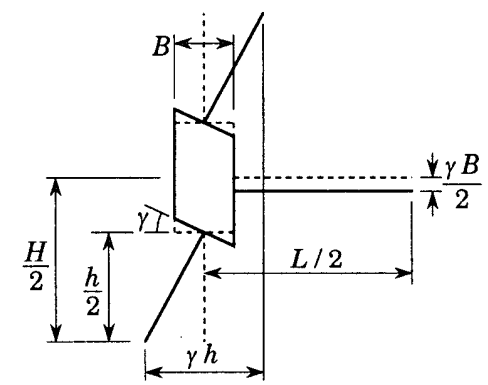

図 8 接合部パネルの弾性変形
ここで, $m$ はパネルに取り付く梁の数であり, 外柱節点では $m=1$, 内柱節点では $m=2$ である。 また, $V_{P}$ はパネル体積である.

接合部パネルの大きさを考えると，梁端部に作用する曲代モーメ ントは節点位置での曲げモーメントの $l / L$ 倍である。また，図 5 に 示すように, 梁端に $\theta$ の弾性変形が生じると, 節点位置での回転角 は $\theta l / L$ となる.したがって, 梁の変形だけを考えると㓮性は(4)式 の $L^{2} / l^{2}$ 倍となる.

反曲点を部材中央と仮定し，節点位置での曲げモーメントを図 6 に示す $M^{*}$ とすると，接合部パネルに作用するせん断力は図7のよう になる、したがって，接合部パネルに作用する曲げモーメントは，節 点位置での曲げモーメント $M^{*}$ の $(h / H-B / L)$ 倍である。図 8 に は，接合部パネルがせん断変形角 $\gamma$ を生じた状態を接合部パネル側 面を回転させない状態で図示している。この図で上下の水平相対変 形は $\gamma h$ であるから, 相対変形角は $\gamma h / H$ となる.さらに図 8 では, 図の右端にあたる梁中央位置にも鉛直変位 $\gamma B / 2$ を生じている。こ の鉛直変位を生じさせないためには,この構造全体を反時計周りに $\gamma B / L$ だけ回転させる必要がある。すなおち，接合部パネルがせん 断変形 $\gamma$ を生じると, この構造の変形角は $\gamma h / H-\gamma B / L$ となる.

梁と接合部パネルに分けて考えたが，節点回転角は，梁の変形と 接合部パネルの变形の和で表されるので, 接合部パネルの弾性変形 および大きさを考慮した梁の曲げ剛性 $K_{B i}^{*}$ は次式となる.

$$
K_{B i}^{*}=\frac{1}{\frac{l^{2}}{L^{2}}\left(\frac{l}{6 E I}+\frac{2}{G A_{s} l}\right)+\frac{m\left(h_{i} / H_{i}-B / L\right)^{2}}{G V_{P}}}
$$

ここで, $h_{i}$ は柱の実長, $H_{i}$ は階高である，上下の階高が異なるとき は, $H_{i}$ は上下の階高の平均值, $h_{i}$ は $H_{i}$ からパネルのせいを減じた值 とする。ささらに, lは梁の実長 (接合部パネル間での内法長さ) $L$ は スパン長 (節点間距離) である. 接合部パネルの左右のスパン長が 異なるときは,(5)式の分母の第1項ついては,対象としている梁につ いての值とし，第2 項では, $L$ は左右のスパン長の平均値とする.

魚骨梁の弾性剛性 $\overline{K_{B}}$ は, 次式で表される。

$$
\overline{K_{B i}}=\Sigma K_{B i}^{*}
$$

3.1.3柱の伸縮を考慮した魚骨梁の岡性

建物のアスペクト比が大きくなると全 体曲げ変形は無視できなくなる.図9に示 すように，付加軸力による柱の軸伸縮は 外柱だけに生じると考えると外梁は剛体 的に回転し, 柱の変形を拘束する剛性が 低下する.図9の例のように長さが異なる スパンがあり，かつ，梁断面が同じなら

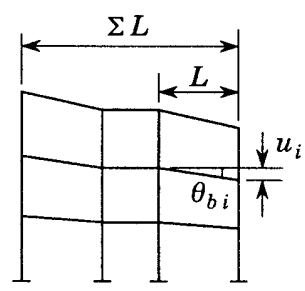

困 9 柱の軸伸縮の影響 内柱にも付加軸力が生じるが, ここでは, 各スパンの梁のせん断力 は一定と考えて, 内柱の付加軸力は無視する。

図 9 に示したように，外柱節点にuの鉛直変位が生じると，外梁 は $\theta_{b}$ 回転する.外梁については, 骨組のせん断変形による節点回転 角 $\theta_{s}$ の他に，外柱の伸縮による節点回転角 $\theta_{b}$ が生じると考える.

$i$ 層の $j$ 番目の梁端節点位置での曲げモーメント $M_{i j}$ と, 骨組の せん断変形による節点回転角 $\theta_{s i j}$ との関係は次式で表される.

$$
M_{i j}=K_{B i j}^{*} \theta_{s i j}
$$

ここで, $K_{B i j}^{*}$ は(5)式で定義した弾性剛性である.

付加軸力による外柱の伸縮を求めるために, 設計用層せん断力 $Q_{i}$ が作用した状態を考える。柱曲げモーメント反曲点が部材中央であ ると仮定して, $i$ 層の外柱に生じる柱付加軸力 $N_{i}$ を次式で近似する.

$$
N_{i}=\frac{\sum_{j=i+1}^{N} Q_{j} H_{j}+\frac{1}{2} Q_{i} H_{i}}{\Sigma L}
$$

ここで $N$ は層数であり, $\Sigma L$ はスパン長の総和（骨組の幅）である.

$i$ 層の外柱の断面積を $A_{i}$, 外柱の伸縮量を $\Delta u_{i}$ とすると, $i$ 層の 梁の外柱側節点の鉛直変位 $u_{i}$ は次式となる。

$$
u_{i}=\sum_{j=1}^{i} \Delta u_{j}=\sum_{j=1}^{i} \frac{h_{i} N_{i}}{E A_{i}}
$$

外柱の軸変形による外梁端部の節点回転角 $\theta_{b i j}$ を次式で近似する.

$$
\theta_{b i j}=s u_{i} / L
$$

ただし,多スパン骨組の場合 $s=1,1$ スパン骨組では $s=2$ となる。 節点回転角 $\theta_{i j}$ は(7)式による $\theta_{s i j}$ と(10)式による $\theta_{b i j}$ の和であり， 外柱の伸縮を考慮した梁端の剛性 $K_{B i j}^{* *}$ は次式となる。

$$
K_{B i j}^{* *}=\frac{M_{i j}}{\theta_{i j}}=1 /\left(\frac{\theta_{b i j}}{M_{i j}}+\frac{1}{K_{B i j}^{*}}\right)
$$

$M_{i j}$ は, 梁のせん断力がすべて等しく, 反曲点は部材中央であると 仮定しているので，次式から求められる.

$$
M_{i j}=\frac{L\left(Q_{i} H_{i}+Q_{i-1} H_{i-1}\right)}{4 \Sigma L}
$$

外柱の軸変形を考虑した魚骨梁の曲げ剛性 $\overline{K_{B i}^{*}}$ は次式となる。

$$
\overline{K_{B i}^{*}}=\Sigma K_{B i j}^{* *}
$$

\section{2 耐力}

\subsection{1 魚骨柱の曲げ而力}

$i$ 層の柱に塑性ヒンジが形成されたときの節点位置でのモーメント ${ }_{C i} M_{p c}^{*}$ は, 次式で表される.

$$
C_{i} M_{p c}^{*}=\frac{H_{i}}{h_{i}} C_{i} M_{p c}
$$

ここで, $C i_{p c} M_{p}$ は軸力に応じて低減された柱の塑性モーメントであ 
る. $i$ 層の魚骨柱の柱頭および柱脚の塑性モーメント $\overline{C_{i} T^{M_{p}^{*}}}$, $\overline{C i B_{B} M_{p}^{*}}$ は次式となる.

$$
\overline{C i T^{M} M_{p}^{*}}=\Sigma_{C i T} M_{p c}^{*} \quad, \overline{C i B} M_{p}^{*}=\Sigma_{C i B} M_{p c}^{*}
$$

3.2.2 魚骨梁の曲げ耐力

梁降伏時の節点位置でのモーメント ${ }_{B}{ }_{i} M_{p}^{*}$ は次式で表される.

$$
{ }_{B i} M_{p}^{*}=\frac{L}{l}{ }_{B i} M_{p}
$$

ここで, ${ }_{B} M_{p}$ は梁の塑性モーメントである.

梁中間荷重の影響で, 梁中間に塑性ヒンジが形成されるときの風 上側モーメント ${ }_{B i} M_{p}^{*}$ は(16)式による ${ }_{B i} M_{p}^{*}$ よりかなり小さくなる. したがって，梁中央集中荷重 $V か ゙$ 作用するときの，風上側端部節点 位置での曲げモーメント ${ }_{B i} M_{p}^{*}$ は次式とする ${ }^{8)}$.

$$
\begin{aligned}
{ }_{B i} M_{p}<\frac{V l}{4} \text { のとき }, & { }_{B i L} M_{p}^{*}=\frac{L}{l}\left(3_{B i} M_{p}-\frac{V l}{2}\right) \\
{ }_{B i} M_{p} & >\frac{V l}{4} \text { のとき },{ }_{B i L} M_{p}^{*}=\frac{L}{l}{ }_{B i} M_{p}
\end{aligned}
$$

また, 風下側端部節点位置での曲げモーメント ${ }_{B i} R_{p}^{*}$ は梁中間荷重 によらず(16)式とする.

$i$ 層の接合部パネルが降伏するときの節点位置での曲げモーメン ト ${ }_{P i} M_{p}^{*}$ は次式で表される。

$$
{ }_{P i} M_{p}^{*}={ }_{P i} M_{p} /\left(\frac{h_{i}}{H_{i}}-\frac{B}{L}\right)
$$

ここで, ${ }_{P i} M_{p}$ は接合部パネルの塑性モーメントである.

以上の值を用いて, 魚骨梁の塑性モーメントは次式で表される。

$$
\overline{B_{i} M_{p}}=\Sigma \min \left({ }_{C i B} M_{p c}^{*}+{ }_{C i T} M_{p c}^{*},{ }_{B i} M_{p}^{*}{ }_{B i R} M_{p}^{*},{ }_{P i} M_{p}^{*}\right)
$$

\section{3 魚骨柱・魚骨梁の履歴モデル}

\subsection{1 魚骨柱の履歴モデル}

魚骨柱の履歴モデルは完全弾塑性型とする。一部の柱が早期に降 伏し剛性が低下する現象は，魚骨梁の履歴モデルに反映される.

\subsection{2 魚骨梁の履歴モデル}

梁降伏型骨組を主な検討対象とした場合, 考察すべき主要な応答 量は梁の塑性変形角である. 魚骨梁の耐力が3.2.2節の耐力を有する 完全弾塑性型の履歴特性を持つとすれば, 各層の梁の塑性変形角の 平均的な值は算定できるが，一部の梁端が早期に降伏し，その梁の 塑性変形角が大きくなることは考慮できない，

同一層の一部の梁端が早期に降伏する原因は, (a)梁中間荷重の影響 による風下側梁端の降伏先行, (b)剛比の高い梁への応力集中, (c)両側 の柱剛性の違いによる梁曲げモーメント反曲点の中央からの移動, (d) 内柱パネルの早期降伏など梁の両端の降伏耐力の違い,などいくつ か挙げられる.(a)の梁中間荷重の影響は塑性履歴の進行によって消滅 するが, (b)〜 (c)等の原因によるとき個々の梁端の荷重－変形関係が 完全弾塑性とすると, その挙動の総和である魚骨梁は, 完全弾塑性 要素の並列結合で表される履歴挙動をとる.

ここでは, 上記の影響を考慮して魚骨梁の復元力特性を図10に示 すTri-linear型とする.ただし, 初期剛性 $\overline{K_{B} i}$, 最大耐力 $\overline{B i} \bar{M}_{p}$ は3.1, 3.2節の值である. 魚骨梁の初期降伏耐力 $\overline{B i}{ }^{M}{ }_{y}$ は, 設計用地震荷重 を比例載荷したとき，その床レベルに最初に塑性ヒンジが形成され るときの梁端曲げモーメント和とする. 設計用地震荷重載荷時の $i$ 層の各梁端の節点位置での曲げモーメントを $M_{i j}$ とすると, 初期降 伏耐力 $\overline{B i} \bar{M}_{y}$ は(16), (17), (18)式による塑性モーメント ${ }_{B i} M_{p}^{*}$ を用い

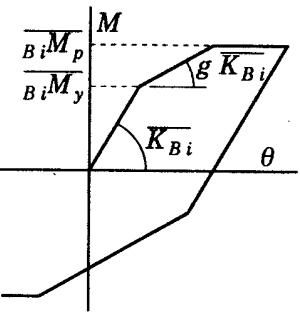

図 10 魚骨梁の履歴モデル

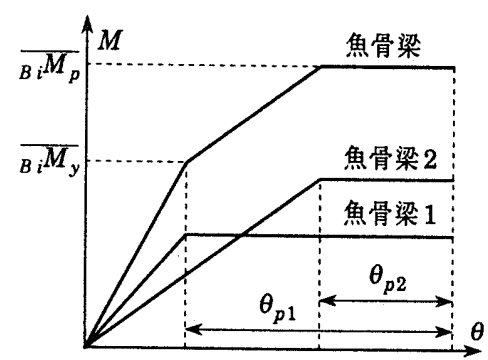

図 11 魚骨梁の塑性変形
て次式で表される。

$$
\overline{B i M_{y}}=\min \left(\frac{B i M_{p}^{*}}{M_{i j}}\right) \Sigma M_{i j}
$$

初期降伏から最大耐力に至る過程では, すべての梁の片方だけが 降伏している状態が平均的な 2 次剛性を与えると仮定する. 弾性状 態では梁の曲げ剛性は両端共に $6 E I / l$ であり，一端に塑性ヒンジ が形成されると, 塑性ヒンジが形成された梁端の剛性は零で他端の 剛性は $3 E I / l$ となるので, 魚骨梁の第 2 分枝剛性比 $g$ は $1 / 4$ とす る。

\subsection{3 梁の累積塑性変形角}

複数の梁で構成さ机るある床レベルにおいて梁の累積塑性変形角 としては最大のものが必要な情報である.ここではいくつかの梁端 のうち先行して降伏する梁端で最大值が生じるものと考える。この 先行降伏する梁端の塑性変形を得るために, Tri-linearのモーメント 一回転角関係を図11のような $2 つ の$ 完全弾塑性要素の並列結合に変 換する. $2 つ の$ 要素のうち, 先行して降伏する要素を魚骨梁 1 とし, その塑性変形角 $\theta_{p 1}$ の絶対值の総和を累積塑性变形角 $\Sigma \theta_{p 1}$ とする. また，後で降伏する要素を魚骨梁 2 とし，その累積塑性変形角を $\Sigma \theta_{p 2}$ とする.魚骨梁 1 だけが降伏している状態では図 12 に示すよ うに梁は片側端だけが塑性変形し，他端は弾性であると考える。梁 端の節点が $\theta$ 回転すると, 塑性ヒンジ側の 梁端には $\theta / 2$ の回転角が生じるので, 塑 性ヒンジの回転角は $3 \theta / 2$ になる.魚骨梁 2も降伏している状態ではすべての梁が一 様に塑性変形する。したがって, 先行して 降伏している梁端の累積塑性変形角 $\Sigma \theta_{p}$

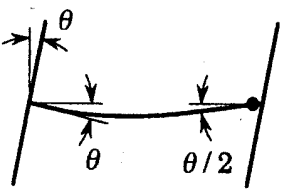

図 12 梁の塑性変形 は次式から得られる。

$$
\Sigma \theta_{p}=\frac{3}{2}\left(\Sigma \theta_{p 1}-\Sigma \theta_{p 2}\right)+\Sigma \theta_{p 2}
$$

ただし，魚骨梁 1 だけが降伏するときは $\theta_{p 2}$ は零である。

魚骨柱の塑性変形は柱の塑性変形を表すが, 魚骨梁の塑性変形は 梁や接合部パネルの塑性変形だけを表すものではない. 柱降伏を予 測した節点に接続される柱端については，魚骨梁の塑性変形は柱端 の塑性変形である。このような柱端については, 柱端の塑性変形は, 魚骨柱の塑性変形と魚骨梁の塑性変形の和として算定される.

\section{4. 数值解析結果}

\section{1 魚骨形モデルとせん断多質点系および骨組モデルとの比較} 魚骨形モデルの妥当性を検討するため魚骨形モデルの応答解析結 果(fishと称する)と一般化塑性ヒンジ法による詳細骨組モデル (club と称する） ${ }^{3)}$ およびせん断型多質点系モデル（shear と称する）の解 析結果を比較する，解析骨組は図 13 に示す 4 層, $6 \mathrm{~m}$ 均等 4 スパン 
AR-04

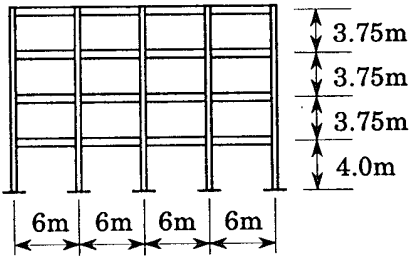

図 13 解析骨組 (AR-04)

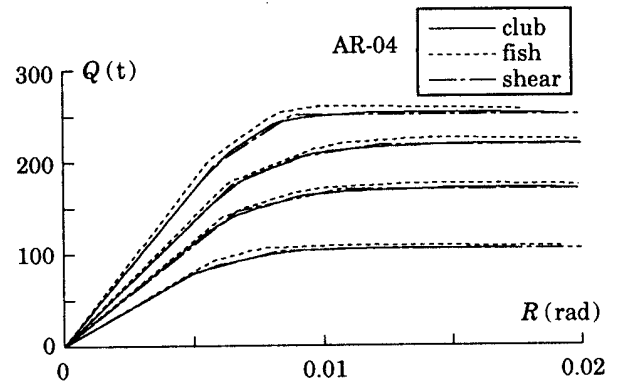

図 14 各モデルの層せん断力一層間変位角関係

のラーメン構造9)である。このAR-04骨組を詳細骨組モデル, 魚骨 形モデル，せん断型多質点系モデルに置換し，弾塑性地震応答解析 により，それぞれの応答值を比較する。

いずれの解析においても，P- $\delta$ 効果は考慮しているが，歪硬化お よび軸力による接合部パネルの耐力変化は無視している。この節の 魚骨形モデルは柱の軸変形による魚骨梁の剛性の低下を考慮してい ない. せん断型多質点系モデルは一般化塑性ヒンジ法による静的弾 塑性増分解析結果を用いて復元力特性を設定した。

各モデルの固有周期を表 1 に, 各層の荷重変形関係を図 14 に示す. fish は clubに比べ約 $2.4 \%$ 固有周期が短くなり，剛性を約 $4.9 \%$ 過大 に評価している。こ机は各層の節点回転角が等しいという拘束条件 を課しているためや全体曲げ変形の影響を無視しているためである. shear は弾性剛性を一致させているため 1 次固有周期は等しいが，2 次固有周期が約 $11 \%$ 大きい. 各層の荷重変形関係も fish は clubに比 較して剛性を若干高めに評価するが,比較的良い一致を示している. 応答解析に用いた入力地震動を表 2 に示す。ここでは，固有周期

表 2 入力地震動

\begin{tabular}{|c|c|r|c|}
\hline Input motion & Max. V. & Max. Acc. & Duration \\
\hline \multirow{2}{*}{ El Centro NS } & $0.5 \mathrm{~m} / \mathrm{sec}$ & $5.11 \mathrm{~m} / \mathrm{sec}^{2}$ & \multirow{2}{*}{$20 \mathrm{sec}$} \\
\cline { 2 - 4 } & $1.0 \mathrm{~m} / \mathrm{sec}$ & $10.22 \mathrm{~m} / \mathrm{sec}^{2}$ & \\
\hline \multirow{2}{*}{ JMA Kobe NS } & $0.5 \mathrm{~m} / \mathrm{sec}$ & $4.70 \mathrm{~m} / \mathrm{sec}^{2}$ & \multirow{2}{*}{$30 \mathrm{sec}$} \\
\cline { 2 - 3 } & $1.0 \mathrm{~m} / \mathrm{sec}$ & $9.40 \mathrm{~m} / \mathrm{sec}^{2}$ & \\
\hline
\end{tabular}
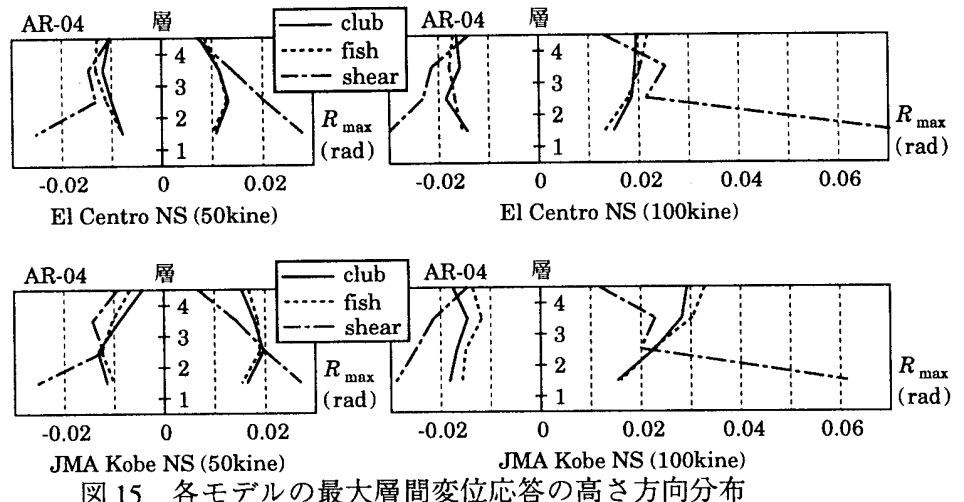

図 15 各モデルの最大層間変位応答の高さ方向分布
の僅かな違いが応答に顕著な影響を及ほすす可能性を排除するために， 次式で定義する損傷に寄与する地震入力エネルギー $E_{d m}$ がclubの応 答値と同じになるように, fish と shearでは各地震動の最大加速度を 調整した。

$$
E_{d m}=\left(E_{e}+E_{p}-E_{g}\right)_{\max }
$$

ここに, $E_{e}$ は弾性歪エネルギー, $E_{p}$ は塑性変形による吸収エネル ギーであり， $E_{g}$ は重力仕事である.

図 15 に各層の最大層間変位角応答を示す. fish は clubの応答値を 良く近似しているが, shearは両者に比較して, 特定層に損傷が集中 する傾向が強く現れる。この骨組は, 柱梁酎力比が内柱で 1.5 前後, 外柱で 3.0 前後となっており, 梁降伏型の特性をもっている. fishで はこの特性が評価できるためclubと同様な結果が得られるが, shear では柱梁強度比の影響は考慮できない。

\section{2 魚骨形モデルによる層間変位および累積塑性变形角の予測}

本節では魚骨形モデルの応答解析結果 (fish) と, 一般化塑性ヒン
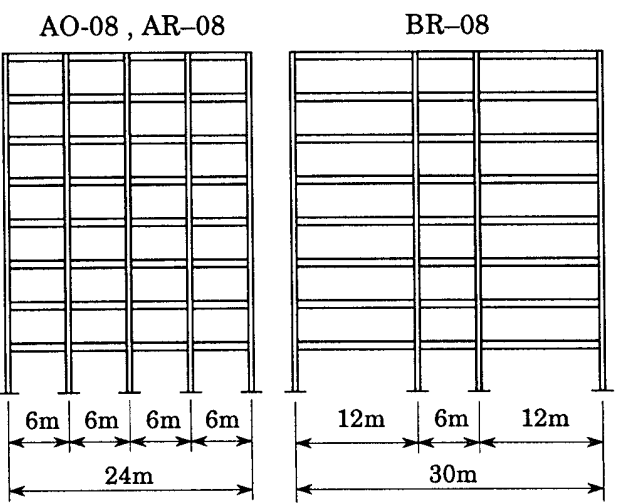

CR-08

図 16 解析骨組
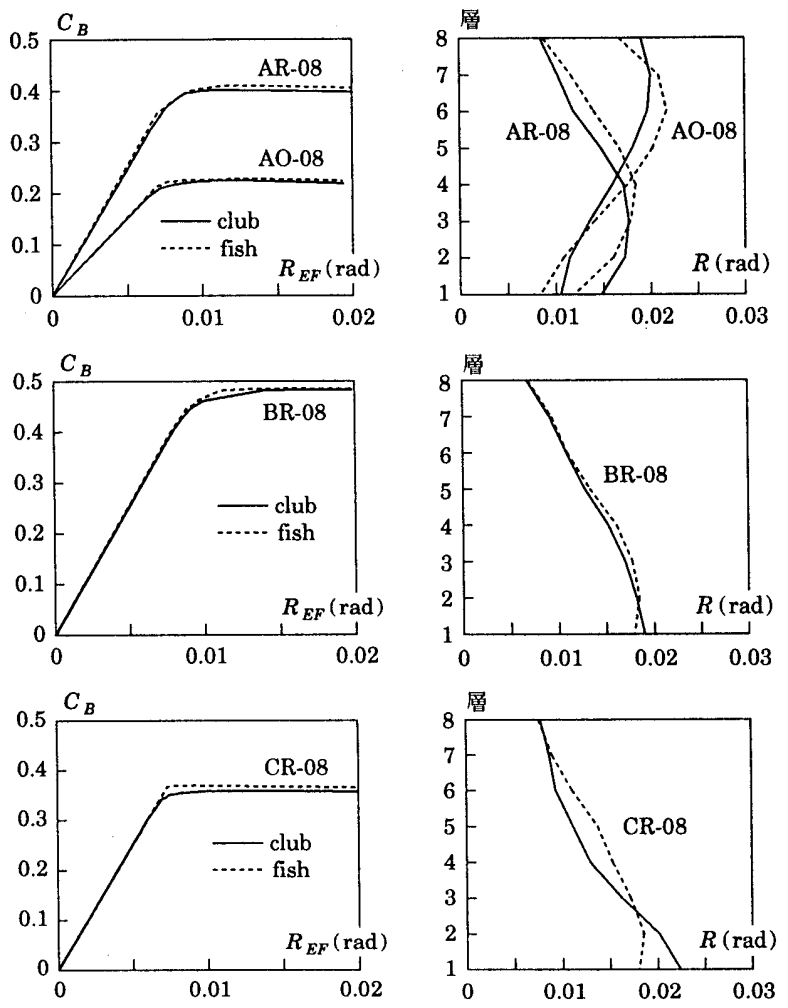

図 $17 C_{B}-R_{E F}$ 関係および $R_{E F}=0.015 \mathrm{rad}$ 時の層間変位角 $R$ 
ジ法による応答解析結果 (club) の比較を行い, 魚骨形モデルの近似 の精度を調べる.解析骨組9は，現行の建築基準法にしたがって設計 したAR-04, AR-08, BR-04, BR-08, CR-04, CR-08の6種，および AR-08と同一形状であるが, $D_{S}=0.25$ として必要保有水平耐力だけを 条件に塑性設計したAO-08の計7種類を用いた。図16に示すように $\mathrm{AR}$ は $6 \mathrm{~m}$ の均等 4 スパン骨組で, BR は $12 \mathrm{~m}, 6 \mathrm{~m}, 12 \mathrm{~m}$ の 3 スパン骨組, CRは $6 \mathrm{~m}$ の単スパン骨組で，それに続く右の数字は層数である。な おここでの解析では, 3.1.3節に示したように柱の軸変形を考慮し て魚骨梁の剛性を低減している。

設計用地震荷重を比例載荷したときの各モデルのベースシヤー係 数 $C_{B}$ と有効構造回転角 $R_{E F}{ }^{10)}$ の関係, および, 有効構造回転角 $R_{E F}$ $=0.015 \mathrm{rad}$ 時の層間変位角 $R_{i}$ の高さ方向分布を図 17 で比較する. 有 効構造回転角 $R_{E F}$ の增分 $\Delta R_{E F}$ は層モーメント $Q_{i} H_{i}$ を重み関数と する層間変位角増分 $\Delta R_{i}$ の平均值であり次式で表される.

$$
R_{E F}=\sum \Delta R_{E F}=\sum \frac{\sum_{i=1}^{N} Q_{i} H_{i} \Delta R_{i}}{\sum_{i=1}^{N} Q_{i} H_{i}}
$$
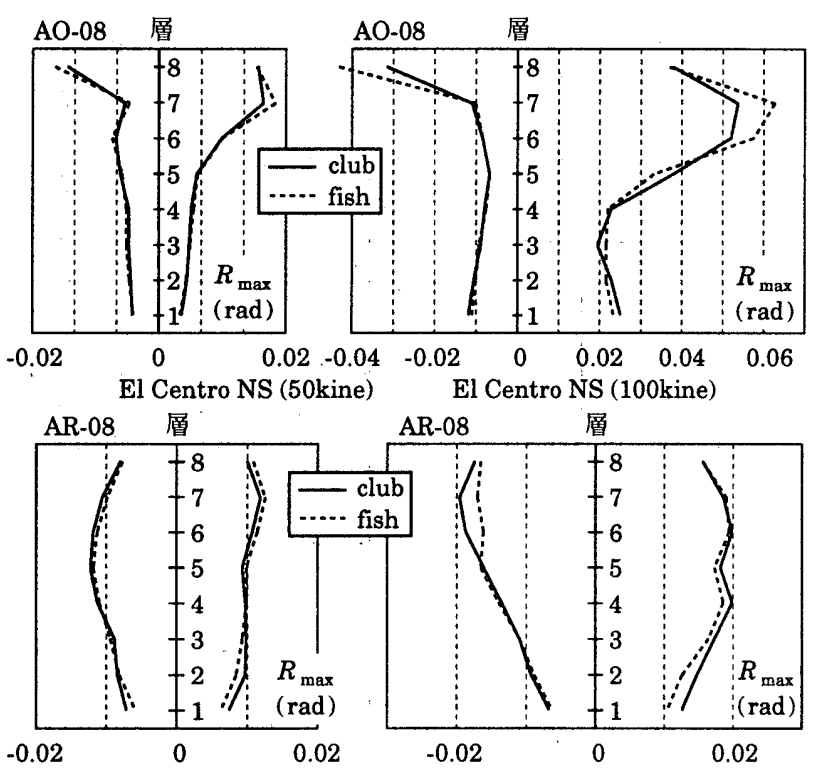

El Centro NS (50kine)

El Centro NS (100kine)

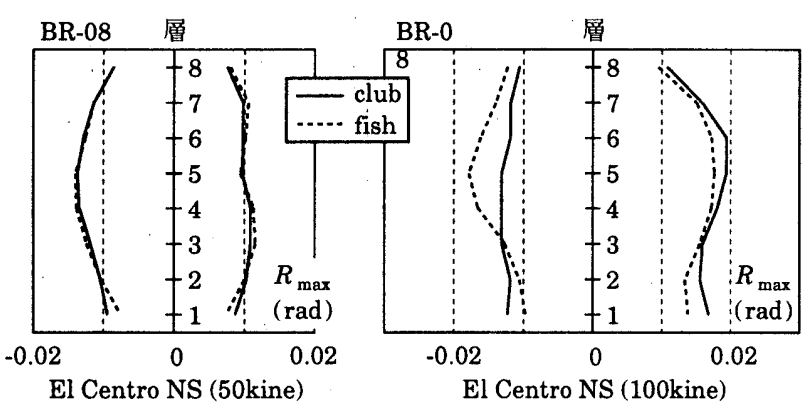

El Centro NS (50kine)

El Centro NS (100kine)

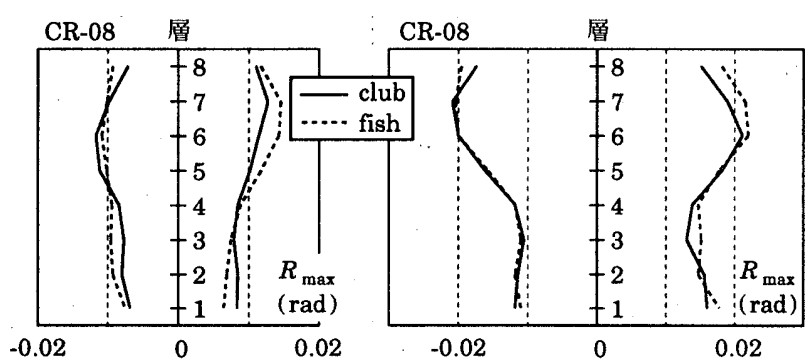

El Centro NS (50kine)
図17によると，2つのモデルの結果はよく一致しており，同等の 保有水平耐力および崩壊機構特性を持つと評価できる.

応答解析に用いた入力地震動は表 2 の通りである．表 3 に各解析 骨組の固有周期を，表 4 に fishの club に対する損傷に寄与する地震 入力エネルギー $E_{d m}$ の比を示す。基本固有周期については, fishは

表 3 各モデルの固有周期 （sec）

\begin{tabular}{|c|c|c|c|c|c|c|c|}
\hline club & AO-08 & AR-04 & AR-08 & BR-04 & BR-08 & CR-04 & CR-08 \\
\hline 1 次 & 1.488 & 0.823 & 1.180 & 0.809 & 1.162 & 0.845 & 1.162 \\
\hline 2 次 & 0.588 & 0.286 & 0.423 & 0.266 & 0.407 & 0.279 & 0.410 \\
\hline fish & AO-08 & AR-04 & AR-08 & BR-04 & BR-08 & CR-04 & CR-08 \\
\hline 1 次 & 1.481 & 0.807 & 1.162 & 0.798 & 1.154 & 0.837 & 1.156 \\
\hline 2 次 & 0.592 & 0.281 & 0.423 & 0.262 & 0.408 & 0.279 & 0.432 \\
\hline
\end{tabular}

表 4 損傷に寄与する地震入力エネルギー $E_{d m}$ の比較

\begin{tabular}{|c|c|c|c|c|c|c|c|}
\hline fish / club & AO-08 & AR-04 & AR-08 & BR-04 & BR-08 & CR-04 & CR-08 \\
\hline El Centro NS 50kine & 1.00 & 0.87 & 0.88 & 0.96 & 0.99 & 0.94 & 0.96 \\
\hline El Centro NS 100kine & 1.04 & 0.98 & 1.00 & 0.95 & 0.95 & 1.01 & 1.02 \\
\hline JMA Kobe 50kine & 1.02 & 1.00 & 0.97 & 0.94 & 1.01 & 1.02 & 0.94 \\
\hline JMA Kobe 100kine & 1.04 & 0.98 & 1.01 & 1.03 & 1.01 & 1.02 & 1.03 \\
\hline
\end{tabular}
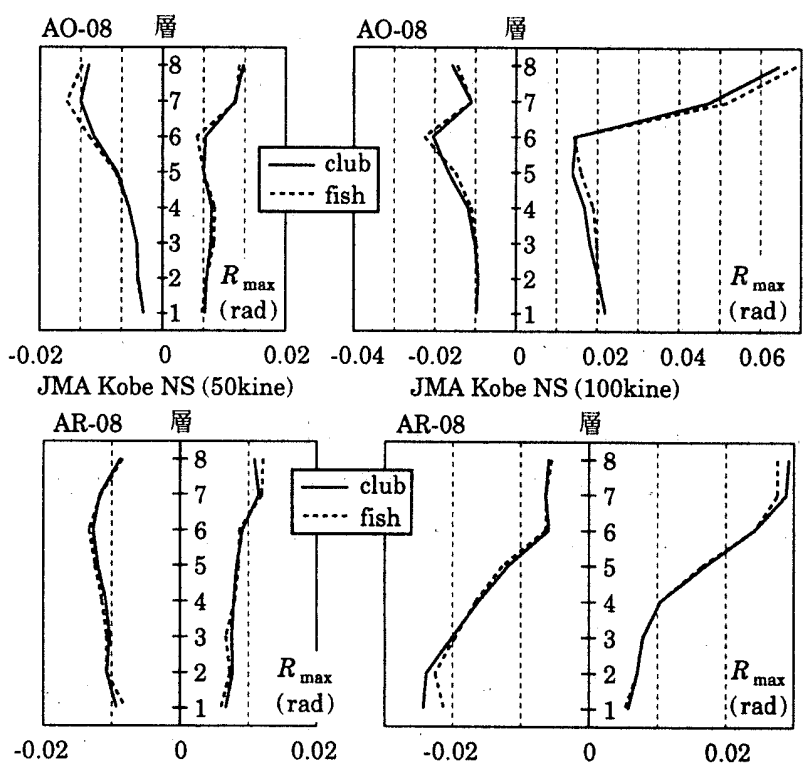

JMA Kobe NS (50kine)

JMA Kobe NS (100kine)
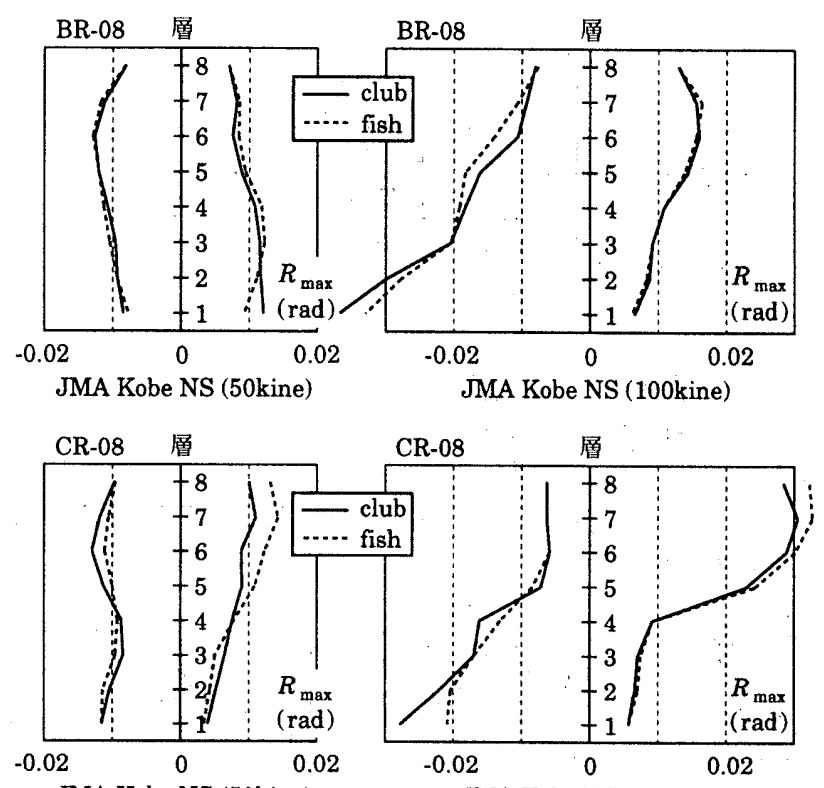

JMA Kobe NS (50kine)

図 18 最大層間変位角の高さ方向分布 

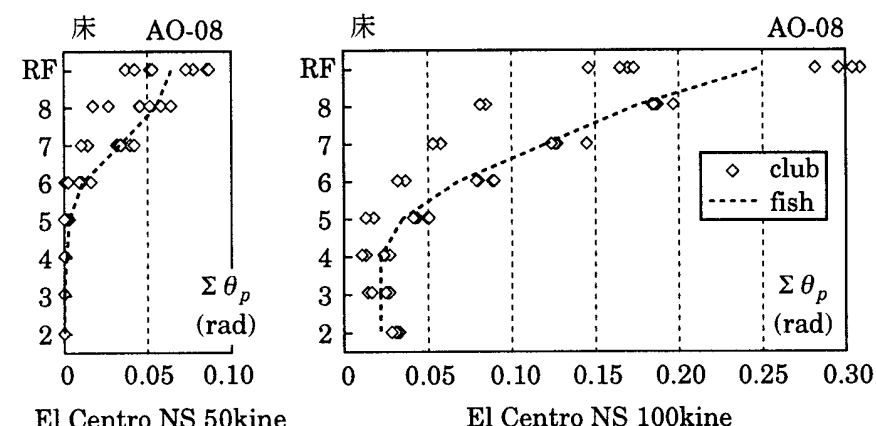

El Centro NS 50kine

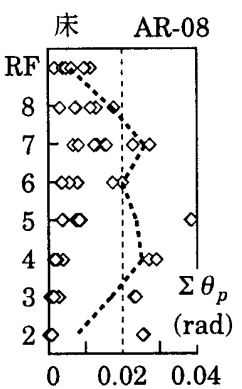

$$
\begin{array}{r}
R \\
8 \\
7 \\
6 \\
5 \\
4 \\
3 \\
2
\end{array}
$$

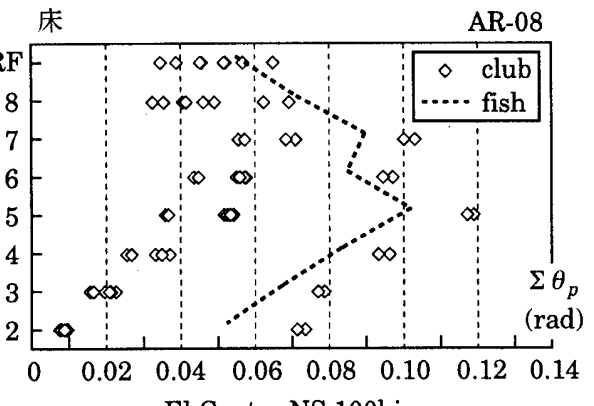

El Centro NS 50kine

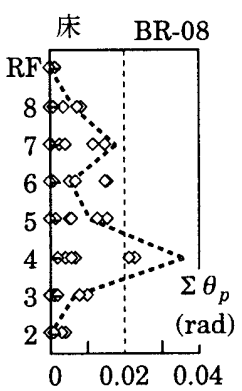

$$
\begin{array}{r}
R \\
8 \\
7 \\
6 \\
5 \\
4 \\
3 \\
2 \\
\end{array}
$$

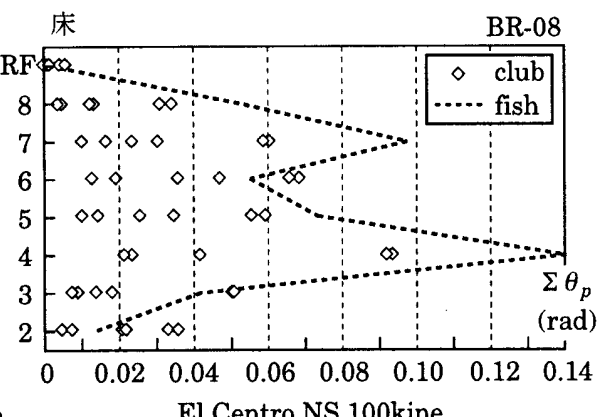

El Centro NS 50kine
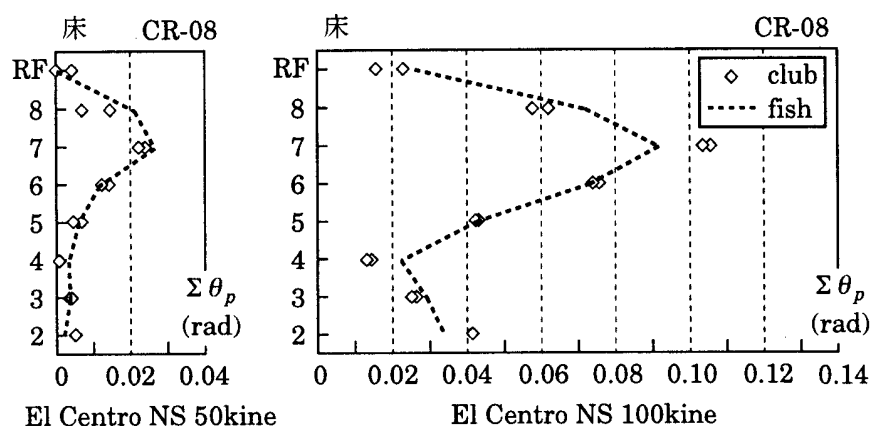
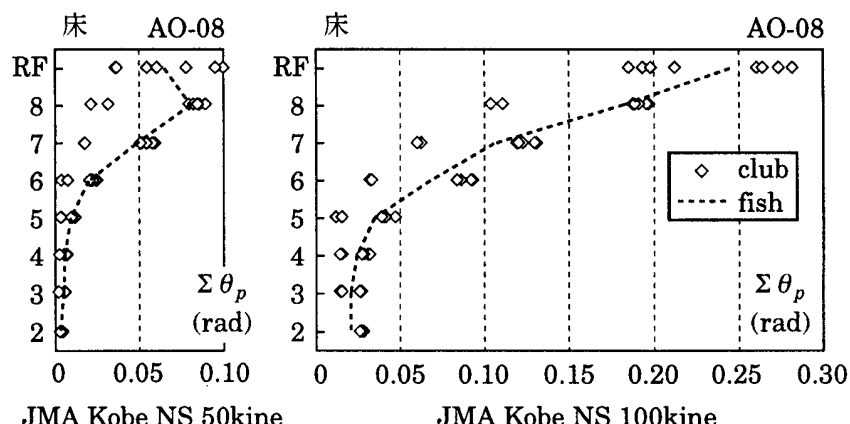

JMA Kobe NS 50kine

JMA Kobe NS 100kine
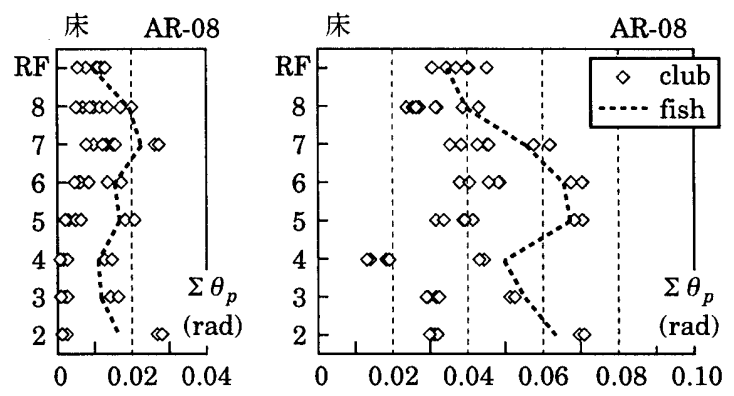

JMA Kobe NS 50kine

JMA Kobe NS 100kine
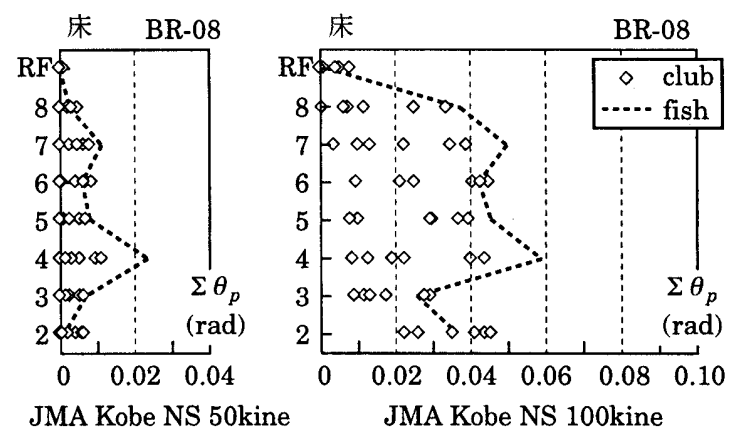

JMA Kobe NS 50kine

JMA Kobe NS 100kine
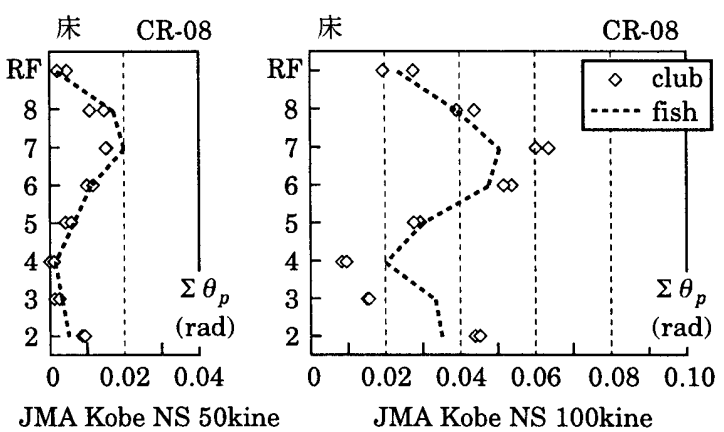

図 19 梁の累積塑性変形角

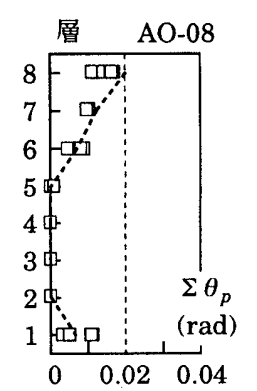

El Centro NS 50kine

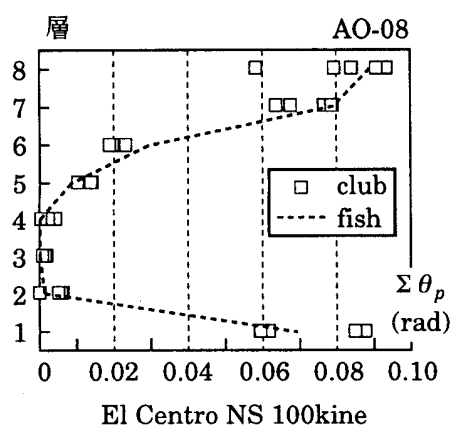

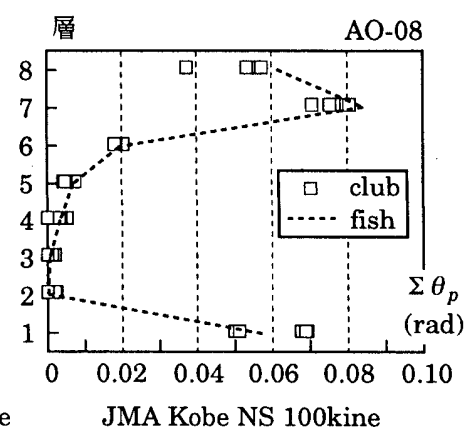

図 20 柱の累積塑性変形角 (AO-08) 
clubに比べ最大 $2 \%$ 程度短くなっているが, 全体曲げ変形の影響を考 慮しているので, 単スパンで多層のCR-08でも暞差は小さい. 損傷 に寄与する入力エネルギーの差は, 最大 1 割程度であり, 大きな違 いは認められない。

図 18 に 8 層骨組の各層の正負 2 方向の最大層間変位角を示す。一 部の層にかなり大きな層間変位角が生じる解析例も含まれているが, fishの応答值は clubの応答值をよく近似している.この結果は, fish によって動的な地震応答過程で形成される崩壊機構が予測できるこ とを示すものと考えている.

図19に梁の累積塑性変形角を示す. 図中〉印は各層のすべての梁 端の clubの応答值であるが, 均等 4 スパンの AO-08やAR-08におい ても同一層の各梁端の累積塑性変形角は大きな差違をもつことがわ かる、破線で示したfishの応答值は(22)式によるものであり, clubに よる各層梁端の応答值の最大值を近似している。

図20にAO-08の柱の累積塑性変形角を示す. 印はすべての柱端 のclubの応答值で, 点線は fishの応答值である. fishの応答值は, club による各層の柱の累積塑性変形角の平均的な値を予測するものであ る.なお, AO-08 以外の骨組では, 柱の塑性変形は, club と fishの いずれにおいても軽微である。

\section{3 柱の軸変形の影響による魚骨梁の剛性低下}

柱の軸変形の影響を調べるために，均等 4 スパンの AR 骨組と影 響が最も大きいと考えられる1スパンのCR骨組について, 柱の軸変 形の影響による魚骨梁の剛性低下について検討した. 3.1.3節に示し た柱の軸変形の影響を考慮した魚骨梁の岡性と, 3.1.2節の柱の軸変 形の影響を無視した剛性との比を，図21に示す。この図によると， CR-08では，柱の軸変形の影響により，魚骨梁の剛性が最大 $64 \% ま$ で低下しており，軸変形が無視し難い影響をもつことがわかる。し かし, 多スパンのAR-04, AR-08ではその影響は小さく, 1スパンの $\mathrm{CR}$ 骨組でも 4層では魚骨梁の剛性低下は $10 \%$ 以下である. 4 層程度 以上の1スパンの骨組を除けば, 柱の軸変形の影響はラーメン骨組 では考虑する必要がないと考える。

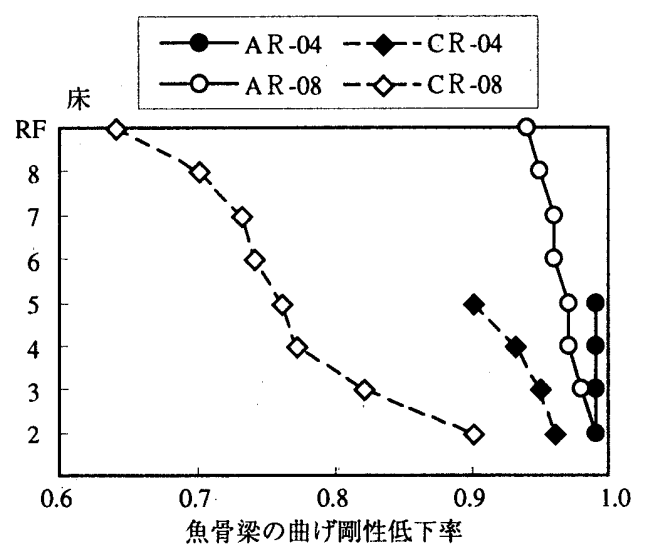

図 21 柱の軸変形による魚骨梁の曲げ岡性低下率の比較

\section{5. 結論}

本論では, 純ラーメン骨組の崩壊型などの特性が再現でき, 部材 レベルの応答も評価可能な動力学モデルとして魚骨形骨組を提案し, 現実的なラーメン骨組を魚骨形骨組へモデル化する手法を示した。
ここで提案した方法によれば, 静的弾性解析と単純な表計算によっ て, 柱・梁・接合部パネルで構成されるラーメン骨組は魚骨形骨組 に置換でき，単純塑性理論による崩壊荷重の計算や弾塑性増分解析 を必要としない。一般的な中低層ラーメン骨組を対象とした数値解 析結果は，以下のようにまとめられる。

(1) 魚骨形モデルは, 固有周期, 地震入力エネルギー, 変位応答, お よび梁端の累積塑性変形について,一般化塑性ヒンジ法による詳 細解析の結果を良く近似する。

（2）せん断型多質点系モデルは，柱梁耐力比など部材間耐力比が考 慮できないため,変形が大きくなると損傷集中を過大に評価する 傾向が強いが,魚骨形モデルは大変形の応答についても良好な近 似を保つ。

（3）単スパンの中層骨組では柱の軸変形の影響による魚骨梁の剛性 低下を考慮する必要があるが, 多スパンの中層骨組や，低層骨組 では考慮する必要はない。

本論の結果は, 実務的な耐震設計における地震応答解析モデルと して，魚骨形モデルがせん断形多質点系モデルに比べて大きな利点 をもつことを明らかにするものである．さらに一般的な骨組の地震 応答が魚骨形モデルから予測できることは，骨組の地震応答に影響 をもつ重要な構造パラメータが単純な魚骨形モデルの構造パラメー タに反映されていることを表す。骨組の構造パラメータと地震応答 との相関関係を検討するための力学モデルとして, 魚骨形モデルは 有用である。

\section{謝辞}

本研究は，建設省総合技術開発プロジェクト/次世代鋼材による 構造物安全性向上技術の開発／「崩壊型と破壊分科会」(主査:井上 一朗）の一部として行われた。 また，解析用骨組の設計は建設省建 築研究所 - 鋼材俱楽部耐震共同研究「数值解析研究会」で行われた. ここに，記して関係各位に深甚なる謝意を表します。

\section{参考文献}

1) R. W. Clough and K. L. Benuska : Nonlinear Earthquake Behavior of Tall Buildings, ASCE EM3, pp.129-146, 1967.6.

2）井上一朗, 永田匡宏: 梁降伏型鋼構造骨組の塑性設計用ベースシャー係数 に関する研究，日本建築学会論文報告集，No.305, pp.29-40, 1981.7 .

3）小川厚治, 多田元英：柱・梁接合部パネルの変形を考留した静的・動的応 答解析プログラムの開発, 第17回情報・システム・利用技術シンポジウム。 pp.79-84, 1994

4）藤本盛久, 和田章, 白方和彦, 小杉立:筋違付鉄骨ラーメンの弾塑性解析 に関する研究，日本建築学会論文報告集，No.209, pp.41-51, 1973, 7.

5）加藤 勉, 秋山 宏: 地震時における銅構造せん断型多層骨組の損伤分布, 日本建築学会論文報告集, No.270, pp.61-68, 1978.8.

6）原田幸博:強震下における多質点せん断系の損傷分布に関する解析的考察, 日本建築学会論文報告集, No.496, pp.99-103，1997.6.

7）上谷宏二, 田川 浩: 梁降伏型骨組の動的崩壊過程における変形集中現象, 日本建築学会論文報告集, No.483, pp.51-60, 1996.5.

8）日本建築学会：建築酎震設計における保有耐力と变形性能（1990）, 丸善, pp.310-319, 1990.

9）井上一朗, 東 清仁, 小川厚治, 多田元英, 長谷川隆：角型銅管·H形銅 梁ラーメン構造の地震応答, その 1 解析骨組の設計, 日本建築学会学術講 演梗既集 C構造 III, pp.269-270, 1995.9.

10) R. Tanabashi, T. Nakamura and S. Ishida : Overall Force-Deflection Characteristics of Multi-story Frames, Proc. of Symp. on Ultimate Strength of Structures and Structural Elements, pp.87-100, 1969. 12. 